\title{
Author Correction: Amylose molecular fine structure dictates water-oil dynamics during deep-frying and the caloric density of potato crisps
}

S. Reyniers (D), N. De Brier (D), N. Ooms (D), S. Matthijs, A. Piovesan (D), P. Verboven, K. Brijs (D), R. G. Gilbert and J. A. Delcour (iD

Correction to: Nature Food https://doi.org/10.1038/s43016-020-00180-x, published online 11 November 2020.

In the version of this Article originally published, the competing interests of the author S. Matthijs were mistakenly omitted. The 'Competing interests' statement has now been updated to read: "S.M. is an employee of the Kellogg Company. All other authors declare no competing interests.”

Published online: 1 December 2020

https://doi.org/10.1038/s43016-020-00204-6

(C) The Author(s), under exclusive licence to Springer Nature Limited 2020 